ACTA THERIOLOGICA

Vol. 29, 4: 45-56, 1984

\title{
Winter Use of Insular Habitat Patches by the Eastern Cottontail
}

\author{
Robert K. SWIHART ${ }^{1}$ \& Richard H. YAHNER ${ }^{2}$
}

\begin{abstract}
Swihart R. K. \& Yahner R. H. 1983: Winter use of insular habitat patches by the eastern cottontail. Acta theriol., 29, 4: 45-56 [With 4 Tables]

Habitat use by eastern cottontails, Sylvilagus floridanus (Allen, 1894) was investigated during two consecutive winters in southeastern Minnesota. Examination of structural characteristics of resting and feeding sites via stepwise discriminant analysis revealed that cottonatails exhibited nonrandom use of habitat, relying on proximity to shrubby vegetation and abiotic cover for diurnal resting sites and nocturnal foraging areas. Shelterbelts were used more than waste areas, and fencerows/roadsides were not used. Provision of shrubs, mature conifers, and artificial cover in shelterbelts and waste areas could promote increased use of these habitat types by cottontails during winter.

[Dept. of Entomol., Fisheries and Wildl., Univ. Minnesota, St. Paul, Minnesota 55108, USA]
\end{abstract}

\section{INTRODUCTION}

Emphasis on cash-crop production in recent years has resulted in more cultivated land throughout the central United States (Vance, 1976). This expansion of agricultural land use plus "clean" farming (e.g., removal of brushy fencerows) have reduced available wildlife habitat to insular patches surrounded by field-crop monocultures (Gottfried, 1979; Wegner \& Merriam, 1979). Although small mammals may traverse extensive fields of row crops in late spring and early summer (Gottfried, 1979), harvesting operations in autumn eliminate crop cover and undoubtedly magnify the insular nature of remaining habitat fragments. Thus, an understanding of vegetative and abiotic features important to wildlife survival in these insular habitats is crucial.

Eastern cottontails, Sylvilagus floridanus, are regarded as habitat generalists (Hanson et al., 1969) but prefer wooded sites during autumn and winter (Johnson \& Hendrickson, 1958; Carson \& Cantner, 1963), especially following autumnal harvest of field crops (Anderson \& Pelton, 1976; Swihart \& Yahner 1982). Habitat features associated with use of various types of wooded habitats in agricultural regions have been examined only qualitatively (e.g., Johnson \& Hendrickson, 1958; Trent \&

Present address: ${ }^{1}$ Museum of Natural History and Department of Systematics and Ecology, University of Kansas, Lawrence, KS 66045, USA. ${ }^{2}$ School of Forest Resources, Forest Resources Laboratory, The Pennsylvania State University University Park, PA 16802, USA. 
Rongstad, 1974), despite the fact that increasingly intensive farming practices are closely linked with declining population levels of cottontails (Edwards et al., 1981) and the fact that knowledge of structural habitat features preferred by cottontails is a prerequisite to proper management of the species (Chapman et al., 1982). Thus, more information is needed regarding the value of wooded habitat types to cottontails and other wildlife (Scott, 1976). Objectives in the present study were (1) to determine whether use of habitat by cottontails in winter was random, (2) to identify biotic and abiotic features associated with habitat use, and (3) to assess use of herbaceous fencerows and roadsides by cottontails as travel corridors between isolated wooded habitats.

\section{STUDY AREA}

The study was conducted at the Rosemount Agricultural Experiment Station, Dakota Co., Minnesota, USA, during winter 1979-80 and 1980-81. Agricultural practices at the Station (and hence habitat fragmentation) were representative of the upper Midwest. Farmstead shelterbelts, waste areas, and fencerows/roadsides were chosen for study. Except for field windbreaks and occasional woodlots, shelterbelts and waste areas generally are the only areas containing woody vegetation in intensively-farmed areas of the central United States. Shelterbelts are multi-row plantings of trees and shrubs that protect farm buildings and livestock during winter by reducing wind velocity and snow drifting when positioned perpendicular to prevailing storm winds (Smith \& Scholten, 1980). In the present study, waste areas are defined as idle land unfit for pasture or cultivation due to edaphic or topographic features. Fencerows/roadsides are narrow strips of vegetation (generally $<15 \mathrm{~m}$ ) adjacent to fenced field borders or secondary roads.

Six study sites were examined, including two each of farmstead shelterbelts, (S1, S2), waste areas (W1, W2), and fencerows/roadsides (F1, F2). Vegetative and structural differences among the habitat types have been presented elsewhere (Swihart \& Yahner, 1982). S1 was an L-shaped, four-row shelterbelt, containing Picea pungens, Picea glauca, Pinus banksiana, Pinus resinosa, Pinus strobus, Thuja occidentalis, Populus deltoides, and Ulmus americana. Mowing prevented growth of woody vegetation between rows on the north-south leg of S1, whereas lack of mowing on the east-west leg resulted in complete enroachment of colonizing woody species between rows. These colonizing species were Rubus occidentalis, Caragana arborescens, Parthenocissus inserta, Sambucus pubens, Fraxinus pennsylvanica, Lonicera tatarica, and Prunus virginiana. S1 was $550 \mathrm{~m}$ from the nearest neighboring tract of woody vegetation. S2, a linear, three-row shelterbelt, consisted of $P$. pungens, Pinus ponderosa, and $L$. tatarica. The $L$. tatarica row was overgrown with Ulmus pumila, Ribes spp., and $R$. occidentalis. S2 was bordered on one side by a small coniferous planting containing 30-year old P. resinosa. Dates of establishment for S1 and S2 were 1946 and 1951, respectively. Waste area study sites (W1 and W2) were adjacent $(<50 \mathrm{~m})$ to each other but differed substantially in density of woody vegetation. W1 was virtually devoid of woody growth, whereas W2 contained small $(<5 \mathrm{~m}$ tall). $U$. pumila and large $\left(>_{15} \mathrm{~m}\right.$ tall) $P$. deltoides. W2 was separated from the nearest wooded site by $400 \mathrm{~m}$. W1 and W2 were established in 1942. Fencerow/roadside study sites (F1 and 
F2) were located on opposite ends of the north-south leg of S1 and consisted entirely of herbaceous vegetation. Major species were Poa pratensis, Trifolium spp., Medicago sativa, Abutilon theophrasti, and Plantago spp.

\section{METHODS}

\section{Field Techniques}

One permanently-marked transect established at each study site was walked at 4- to 8-day intervals between 0900-1500 hours from 5 December 1979 to: 2 March 1980 and from 11 December 1980 to 8 March 1981. Transects followed the major axis of study sites in a zig-zag fashion to increase area traversed and to obtain a strip width of $15 \mathrm{~m}$ on each side of a transect; this $15-\mathrm{m}$ width approximates the maximum flushing distance of rabbits (Anderson \& Pelton, 1976). Each transect was traversed to flush rabbits and to locate diurnal resting

Table 1

Habitat variables measured for experimental units (form sites, pellet groups, and random points) and used in stepwise discriminant analyses of habitat use by eastern cottontails at the Rosemount Agricultural Experiment Station, Dakota Co., Minnesota, USA. Variables with an asterisk were used only in analyses of study sites containing these features. S2, F1, and F2 did not contain artificial cover sites or animal burrows.

Acronym

Definition

ARTDIS * Distance $(m)$ from experimental unit to the nearest artificial cover (e.g., abandoned shed, junkpile) $>2.0 \mathrm{~m}^{2}$

BURROW * Distance $(\mathrm{m})$ from experimental unit to the nearest animal burrow $>15 \mathrm{~cm}$ in diameter

$\mathrm{DBHO}^{*} \quad$ Diameter at breast height $(\mathrm{cm})$ of the tree nearest to the experimental unit and $>7.5 \mathrm{~cm}$ diameter at breast height

DBHU Same as DBHO, but for trees $<7.5 \mathrm{~cm}$ diameter at breast height

DISTO Distance $(\mathrm{m})$ from experimental unit to nearest tree with a diameter at breast height $>7.5 \mathrm{~cm}$

DISTU Same as DISTO, but for trees $<7.5 \mathrm{~cm}$ diameter at breast height

SHRUB Distance $(m)$ from experimental unit to the nearest shrubby vegetation $<1.0 \mathrm{~m}$ tall and occurring at a density $>10$ stems per $\mathrm{m}^{2}$

STEM Number of live woody stems within a $1.0-\mathrm{m}^{2}$ circle centered on the experimental unit

sites ("forms"; Marsden \& Holler, 1964) and then was walked in the opposite direction to locate nocturnal activity centers as depicted by pellet groups (Brown, 1961; Lord, 1963).

Direction of escape route was recorded for each cottontail flushed from forms. Data collected for each form included location and measurements of eight biotic and abiotic variables surrounding the form (Table 1). All pellet groups $(>2$ pellets $/ \mathrm{m}^{2}$ ) within $1 \mathrm{~m}$ of a transect were counted; each pellet group was delineated by a $1-\mathrm{m}^{2}$ circle centered at the point of greatest fecal deposition. For each group, location, number of pellets, percentage of browsed woody stems within a $1-\mathrm{m}^{2}$ circle, and eight habitat variables (Table 1) were noted. Pellets then were removed to prevent recounting. $S$. floridanus pellets were distinguished from pellets of sympatric (but uncommon) whitetailed jackrabbits, Lepus townsendii, by size (e.g., Lord, 1963; Arnold \& Reynolds, 1943). 
To compare the observed habitat structure chosen by cottontails with the structure expected if cottontails used habitat randomly, random points $(n=92)$ were quantified at various times during the study while walking pellet transects. The number of random points measured per habitat type was proportional to the distance walked in each habitat type. Habitat variables (Table 1) measured at random points were identical to those measured at forms and pellet groups.

\section{Data Analysis}

Stepwise discriminant analyses (BMDP7M; Dixon \& Brown, 1979) were conducted on four two-group data sets: 1) total form sites versus random points in all study sites, 2) shelterbelt pellet groups versus random points in shelterbelts only, 3) S1 pellet groups versus random points in S1 only, and 4) waste area pellet groups versus random points in waste areas. The last two data sets were analyzed using eight habitat variables (Table 1), whereas the first two sets involved only six variables because artificial cover (e.g., abandoned sheds, junkpiles, brushpiles) and animal burrows were absent from S2. Habitat use was similar for both winters, despite a halving of population density in 1980 to 3.5 rabbits/ha (Swihart \& Yahner, 1982). Hence, data from both winters were pooled for all analyses.

Stepwise discriminant analyses also were used to compare pellet groups categorized into two additional two-group data sets: 1) months (December-January vs. February-March) and 2) habitat types (shelterbelts vs. waste areas). $F$-values of 4.00 and 3.96 were used for determining variable entry and removal in the stepping process for each discriminant analysis. Rao's $F$ (Rao, 1973) was computed to test for segregating ability of the discriminant function; canonical values of group means, canonical coefficients of selected habitat variables, and $F$-to-enter values for selected variables were calculated. In addition, variance inflation factors were used to assess multicollinearity among the habitat variables (Chatterjee \& Price, 1977; Cavallaro et al., 1981). Variance-stabilizing square root transformations were performed on habitat variables prior to all statistical analyses unless otherwise stated (Chatterjee \& Price, 1977). Univariate tests included KruskalWallis test (Conover, 1971) and 2-sample $t$-tests for groups with unequal variances (Brownlee, 1965).

\section{RESULTS}

\section{Form Sites}

Twenty-nine form sites from 34 flushes of rabbits were noted during 25 walking sessions traversing $65.2 \mathrm{~km}$. Shelterbelts, waste areas, and fencerow 3 /roadsides accounted for 25 , four and no forms, respectively. All flushes occurred either in shelterbelts $(n=30)$ or in W2 $(n=4)$. Flushing frequencies were $0.87 / \mathrm{km}$ in shelterbelts and $0.20 / \mathrm{km}$ in waste areas.

Characteristic s of form sites were significantly different from those of random points (Table 2; Rao's $F_{3,117}=10.24, P<0.01$ ). DISTO, STEM, and DBHU contributed to group separation. In general, form sites were closer to overstory trees, surrounded by a greater number of woody stems, and associated with larger sapling-size trees compared to random points. 
Form sites in $\mathrm{S} 1$ were closer to artificial cover $\left(t_{42}=2.77, P<0.01\right)$ and animal burrows $\left(t_{35}=3.08, P<0.01\right)$ than were random points. Likewise, forms in waste areas were located nearer to burrows than random points $\left(t_{23}=3.85, P<0.001\right)$. However, random points were closer to artificial cover in waste areas compared to forms $\left(t_{5}=-2.44\right.$, $0.05<P<0.10)$.

Table 2

Stepwise discriminant analysis of total form sites $(n=29)$ versus random points $(n=92)$ in all study sites using transformed habitat variables measured at form sites and random points. Variables are arranged in order of entry into the discriminant function, and all are significant $(P<0.01)$. Means $(\bar{x})$ and standard errors $(S E)$ are for untransformed values.

\begin{tabular}{|c|c|c|c|c|c|}
\hline \multirow[b]{2}{*}{ Variable } & \multirow[b]{2}{*}{$F$-to-enter } & \multicolumn{2}{|c|}{ Form sites } & \multicolumn{2}{|c|}{ Random points } \\
\hline & & $\bar{x}$ & $S E$ & $\bar{x}$ & $S E$ \\
\hline DISTO & 15.74 & 3.9 & 0.8 & 27.6 & 4.8 \\
\hline STEM & 6.58 & 11.6 & 2.1 & 5.8 & 1.1 \\
\hline DBHU & 6.58 & 2.6 & 0.2 & 2.3 & 0.1 \\
\hline Canonical values & of group means: & -0.90 & & 0.28 & \\
\hline
\end{tabular}

Form sites quantified in early winter (December-January) differed from those in late-winter (February-March) with respect to two habitat variables. DISTO was significantly larger for early-winter forms compared to those in late winter (Kruskal-Wallis $T_{1}=4.75, P<0.05$ ), and SHRUB was significantly smaller for early- versus late-winter resting sites $\left(T_{1}=5.79, P<0.05\right)$. STEM was greater for form sites in shelterbelts than sites in waste areas $\left(T_{1}=3.99, P<0.05\right)$. Further, SHRUB was less in shelterbelts than in waste areas $\left(T_{1}=3.16,0.05<P<0.10\right)$, and ARTDIS was significantly less in $\mathrm{S} 1$ than in W2 $\left(T_{1}=6.02, P<0.05\right)$.

\section{Pellet Groups}

Fecal pellet transects were completed for 15 sessions totaling $38.8 \mathrm{~km}$. No pellet groups were encountered in W1, F1, or F2, whereas 31,43 , and 138 groups were noted in W2, S2, and S1, respectively. Pellet groups occurred at a rate of $2.58 / \mathrm{km}$ and $8.86 / \mathrm{km}$ for waste area and shelterbelt habitat types, respectively.

Pellet groups and random points in waste areas differed significantly with respect to DISTU, BURROW, DBHU, and SHRUB (Table 3; $F_{4,40}=21.99, P<0.01$ ). In waste areas, mean distances to sapling-size trees, burrows, and shrubby vegetation were less at pellet groups than at random sites, and presence of larger-sized saplings characterized areas around pellet groups. Pellet groups and random points in shelterbelts also were distinct $\left(F_{5,28 s}=17.16, P<0.01\right)$ due to STEM, DISTO, DISTU, 
DBHO, and DBHU (Table 3). In shelterbelts, woody stem density and diameters of proximal overstory and sapling-size trees were greater for pellet groups compared to random points, whereas distances to the nearest tree in each size class were smaller for pellet groups relative to random points (Table 3). Pellet groups and random points collected in S1 were segregated by four habitat variables (Table $3 ; F_{4,153}=16.22, P<0.01$ ). Means for ARTDIS, DISTU, STEM, and DISTO differed significantly between these two groups; in general, pellet groups in S1 were closer to both artificial cover and trees of each size class and were surrounded by a greater number of woody stems than were random points.

Table 3

Stepwise discriminant analyses of pellet groups versus random points in waste areas, both shelterbelts, and S1 separately. All variables are significant $(P<0.05)$. Means $(\bar{x})$ and standard errors $(S E)$ represent untransformed values.

\begin{tabular}{|c|c|c|c|c|c|c|c|c|c|c|}
\hline \multirow[b]{2}{*}{ Variable } & \multirow[b]{2}{*}{$F$-to-enter } & \multirow{2}{*}{$\begin{array}{c}\text { Cano- } \\
\text { nical } \\
\text { coeff. }\end{array}$} & \multirow{2}{*}{\multicolumn{2}{|c|}{$\begin{array}{l}\begin{array}{l}\text { Canonical } \\
\text { values of } \\
\text { group means }\end{array} \\
\text { Pellet Random }\end{array}$}} & \multirow[b]{2}{*}{$\mathrm{n} \bar{x}$} & \multicolumn{2}{|c|}{ Pellet } & \multicolumn{3}{|c|}{ Random } \\
\hline & & & & & & $S E$ & $\mathrm{~N}$ & $\bar{x}$ & $S E$ & $\mathrm{~N}$ \\
\hline \multicolumn{11}{|c|}{ Waste area } \\
\hline DISTU & 38.54 & 1.05 & -1.24 & 1.70 & 0.8 & 0.1 & 26 & 6.7 & 1.3 & 19 \\
\hline BURROW & 13.92 & 0.29 & & & 28.0 & 3.5 & & 46.8 & 7.6 & \\
\hline DBHU & 5.38 & -0.93 & & & 3.2 & 0.4 & & 2.6 & 0.3 & \\
\hline SHRUB & 4.81 & 0.30 & & & 4.3 & 0.9 & & 14.6 & 2.5 & \\
\hline \multicolumn{11}{|c|}{ Shelterbelt } \\
\hline STEM & 25.17 & -0.36 & -0.34 & 1.07 & 13.1 & 0.6 & 181 & 9.3 & 1.6 & 58 \\
\hline DISTO & 28.33 & 0.60 & & & 3.6 & 0.2 & & 6.7 & 0.8 & \\
\hline DISTU & 8.41 & 0.57 & & & 1.7 & 0.1 & & 3.6 & 0.8 & \\
\hline DBHO & 9.66 & -0.38 & & & 23.1 & 0.7 & & 19.7 & 1.2 & \\
\hline DBHU & 5.58 & -0.74 & & & 2.4 & 0.1 & & 2.2 & 0.2 & \\
\hline \multicolumn{11}{|c|}{ S1 } \\
\hline ARTDIS & 26.51 & 0.16 & -0.26 & 1.61 & 27.8 & 3.4 & 158 & 84.6 & 16.4 & 22 \\
\hline DISTU & 16.53 & 0.42 & & & 1.7 & 0.2 & & 4.7 & 1.5 & \\
\hline STEM & 7.20 & -0.32 & & & 12.6 & 0.7 & & 6.4 & 1.7 & \\
\hline DISTO & 7.76 & 0.46 & & & 2.6 & 0.2 & & 5.4 & 1.4 & \\
\hline
\end{tabular}

SHRUB and DISTU accounted for temporal differences between pellet groups collected in early winter (December-January) versus pellet groups tallied in late winter (February-March; $F_{2,209}=8.42, P<0.01$; Table 4). Pellet groups encountered during early winter averaged smaller distances to shrubby vegetation but greater distances to sapling-size trees than late-winter groups.

Pellet groups in waste areas and shelterbelts were separated by DISTO and SHRUB (Table $4 ; F_{2,209}=55.40, P<0.01$ ); mean distances to overstory trees and shrubby vegetation were greater for waste area pellet groups than for shelterbelt pellet groups. 


\section{DISCUSSION}

\section{Habitat Features Associated With Nonrandom Use}

Cottontails clearly did not use habitat in a random manner (Tables $2,3)$. For example, form sites were closer to overstory trees, surrounded by more woody stems, and associated with larger sapling-size trees than would be expected if forms were distributed randomly throughout the habitat (Table 2). Friley (1955) noted that rabbits commonly used forms located at bases of trees and shrubs. During winter, this behavior may decrease exposure to prevailing winds, thereby facilitating homeothermy and minimizing energy expenditures (after Gordon et al., 1968). Thermoregulation may be especially critical at the Station in winter; windchill readings of $-35^{\circ} \mathrm{C}$ were not unusual. In addition, rabbits typically exhibit an increased reliance on shrubby form sites during winter,

Table 4

Stepwise discriminant analyses conducted for pellet groups collected in different months (December-January versus February-March) and in waste areas (W) versus shelterbelts $(S)$. Means $(\bar{x})$ and standard errors $(S E)$ are untransformed values. $P<0.05$ for all variables listed.

\begin{tabular}{|c|c|c|c|c|c|c|c|c|c|c|}
\hline \multirow[b]{2}{*}{ Variable } & \multirow[b]{2}{*}{$F$-to-enter } & \multirow{2}{*}{$\begin{array}{c}\text { Cano- } \\
\text { nical } \\
\text { coeff. }\end{array}$} & \multicolumn{2}{|c|}{$\begin{array}{l}\text { Canonical values } \\
\text { of group means }\end{array}$} & \multicolumn{3}{|c|}{ Group 1} & \multicolumn{3}{|c|}{ Group 2} \\
\hline & & & Group 1a & Group 2a & $\bar{x}$ & $S E$ & $\mathrm{~N}$ & $\bar{x}$ & $S E$ & $\mathrm{~N}$ \\
\hline \multicolumn{11}{|c|}{ Months (all study sites) } \\
\hline $\begin{array}{l}\text { SHRUB } \\
\text { DISTU }\end{array}$ & $\begin{array}{l}9.45 \\
7.11\end{array}$ & $\begin{array}{r}0.87 \\
-0.93\end{array}$ & 0.34 & -0.23 & $\begin{array}{l}0.9 \\
1.8\end{array}$ & $\begin{array}{l}0.2 \\
0.2\end{array}$ & 85 & $\begin{array}{l}1.8 \\
1.4\end{array}$ & $\begin{array}{l}0.2 \\
0.2\end{array}$ & 127 \\
\hline \multicolumn{11}{|c|}{$W$ vs $S$} \\
\hline $\begin{array}{l}\text { DISTO } \\
\text { SHRUB }\end{array}$ & $\begin{array}{l}64.73 \\
35.45\end{array}$ & $\begin{array}{l}-0.71 \\
-0.73\end{array}$ & -0.71 & 0.30 & $\begin{array}{r}16.6 \\
4.3\end{array}$ & $\begin{array}{l}2.5 \\
0.9\end{array}$ & 31 & $\begin{array}{l}3.6 \\
1.0\end{array}$ & $\begin{array}{l}0.2 \\
0.1\end{array}$ & 181 \\
\hline
\end{tabular}

a Group 1=December-January; Group 2=February-March and $S$ for the two analyses, respectively.

presumably in response to reductions in herbaceous cover (Allen, 1939; Kline \& Hendrickson, 1954). In the present study, reliance on shrubby vegetation near form sites peaked in early winter, but mean distance to overstory trees was greater at this time (Table 4). Accumulations of drifting snow (occasionally $>1 \mathrm{~m}$ ) in shelterbelts and in waste areas during late winter covered a large proportion of shrubby growth suitable for resting-site use by cottontails. Consequently, individuals used sites proximal to trunks of mature trees as alternative sites for resting in late winter.

Woody vegetation is essential to rabbits in winter as a source of food (Fitzsimmon3, 1978), resting sites (Table 2), and escape cover (Linder 
and Hendrickson, 1956). Thus, cottontails in our study concentrated activities in areas characterized by greater stem densities relative to random areas (Table 3). Habitat features associated with nocturnal activity centers also exhibited seasonal shifts. For example, distances of pellet groups to shrubs were greater and distances to sapling-size trees were less in late winter relative to early winter. Such shifts might have resulted if cottontails were forced to browse on small trees as drifting snow covered shrubby vegetation.

In waste areas, distances of pellet groups to small trees, burrows, and shrubs were less than corresponding distances of random points, suggesting a preference by foraging rabbits for areas proximal to these features (Table 3). Larger sapling-size trees also were associated with pellet groups in this habitat type. Pellet groups in shelterbelts were associated distinctly with densely-wooded sectors compared to random points (Table 3). Bruna (1952) noted that cottontails preferred denser, woody cover in winter relative to other seasons, and Bresiński \& Chlewski (1976) showed that European hares, Lepus capensis, preferred shelterbelts with dense undergrowth. In our study, $77 \%$ of all pellet groups quantified in $\mathrm{S} 1$ were encountered in the shrubby, unmowed east-west leg. Artificial cover proximal to pellet groups also characterized sites quantified in S1 (Table 3). The importance of artificial cover to rabbits as refugia is well-documented (Haugen, 1943; Trent \& Rongstad, 1974). Burrows occurred in S1, but they frequently were buried under snow with no observed access to entrances.

\section{Comparison of Habitat Types}

Pellet groups in shelterbelts were characterized by smaller distances to both shrubby vegetation and overstory trees relative to groups in waste areas (Table 4), and form sites in shelterbelts were surrounded by more shrubby vegetation than forms in waste areas. Shelterbelts contained greater amount of woody vegetation than waste areas; consequently, shelterbelts appear better suited than waste areas as cottontail habitat in winter. Compared to waste areas, flushing frequencies were 4.4 times greater and pellet groups were encountered 3.4 times more frequently in shelterbelts. This pattern was evident for both winters. We view these frequencies as approximate indicators of relative population density in shelterbelts and waste areas. Hence, if relative population density and stability are positively related to habitat suitability (after Ricklefs, 1976), then shelterbelts are better suited for cottontail use compared to waste areas in winter, and waste areas are more suitable than fencerows/ roadsides. 
Burrows conceivably enabled rabbits to inhabit W2 during winter; Linduska (1947) and Grizzell (1955) emphasized the importance of woodchuck, Marmota monax, burrows to $S$. floridanus survival in sparselywooded habitat types. However, study sites containing abiotic cover but lacking woody vegetation (e.g., W1) were not used during winter in this study.

Bruna (1952) observed that removal of brushy cover along fencerows eliminated travel lanes for rabbits, and Vance (1976) blamed reductions of fencerow habitat for declines in cottontail population. Fencerows/ roadsides at the Station connecting wooded sites lacked brushy cover. No flushes, pellet groups, or tracks were observed in F1 or F2 during winter, attesting to the affinity of cottontails for wooded sites and to the isolation of wooded sites at this time of the year. Indeed, we found no evidence that cottontails ventured beyond the borders of shelterbelts and waste areas during either winter. Thus, we believe that wooded fragments of habitat (e.g., S1, W2) may be viewed as islands surrounded by unoccupied harvested fields, fencerows, and roadsides (after Petras \& Topping, 1981). Extreme isolation of a habitat fragment increases the likelihood of local extinctions of populations via lowered colonization rates (Brown \& Kodric-Brown, 1977; Smith, 1980). However, isolation of wooded habitat types conceivably is restricted to the winter because cottontails may disperse through croplands during the growing season (Gottfried, 1979).

In summary, cottontails did not use individual habitat patches in a random manner. Rather, a premium was placed on sites that were proximal to shrubby vegetation and abiotic cover, such as animal burrows and abandoned sheds. Differences also existed regarding use of the various patches. Shelterbelts appeared to be the best habitat for cottontails during winter, followed by the wooded waste area. Entirely herbaceous habitat, such as fencerows and roadsides, were unused by cottontails during this season. Based on these findings, we believe that increased use of shelterbelts and waste areas could be promoted by planting shrubs (Lonicera, Viburnum, Prunus) and conifers (Picea), as well as by placing artificial cover in these habitats. Encouraging establishment of colonizing shrubs such as Rubus, Ribes, and Sambucus also would enhance the value of shelterbelts and waste areas to cottontails in winter.

Acknowledgments: We thank James A. Cooper, Peter A. Jordan, Harold Scholten, and Norman A. Slade for reviewing the manuscript. Funds for this study were provided by the University of Minnesota Graduate School, by the Minnesota Agricultural Experiment Station, and by grants from the National Rifle Association of America and the Max McGraw Wildlife Foundation. Computer expenses were 
defrayed by the University of Minnesota Computer Center. This is paper number 11817 of the Scientific Journal Series, Minnesota Agricultural Experiment Station, University of Minnesota.

\section{REFERENCES}

1. Allen D. L., 1939: Michigan cottontails in winter. J. Wildl. Manage., 3: 307-322.

2. Anderson B. F. \& Pelton M. R., 1976: Movements, home range, and cover use: factors affecting the susceptibility of cottontails to hunting. Proc. Conf. Southeast. Assoc. Fish and Wildl. Agencies, 30: 525-535.

3. Arnold J. F. \& Reynolds H. G., 1943: Droppings of Arizona and antelope jack rabbits and the "pellet census". J. Wildl. Manage., 32: $835-841$.

4. Bresiński W. \& Chlewski A., 1976: Tree stands in fields and spatial distribution of hare populations. [In: "Ecology and management of European hare populations", eds. Z. Pielowski, Z. Pucek]. Państw. Wyd, Roln. i Leśne: 185-193. Warszawa.

5. Brown J. H. \& Kodric-Brown A., 1977: Turnover rates in insular biogeography: effect of immigration on extinction. Ecology, 58: 445-449.

6. Brown L. N., 1961: Excreted dyes used to determine movements of cottontail rabbits. J. Wildl. Manage., 25: 199-202.

7. Brownlee K. A., 1965: Statistical theory and methodology in science and engineering. John Wiley: New York.

8. Bruna J. F., 1952: Kentucky rabbit investigations. Kentucky Dept. Fish and Wildl. Res. Pittman-Robertson Proj. No. W-26-R.

9. Carson J. D. \& Cantner D. E., 1963: West Virginia cottontails. West Virginia Dept. Nat. Res. Bull. No. 5.

10. Cavallaro J. I., Menke J. W. \& Williams W. A., 1981: Use of discriminant analysis and other statistical methods in analyzing microhabitat utilization of dusty-footed woodrat. [In: "The use of multivariate statistics in studies of wildlife habitat", D. E. Capen, ed.]. USDA For. Service Gen. Tech. Rep. RM-87: 222-231.

11. Chapman J. A., Hockman J. G. \& Edwards W. R., 1982: Cottontails. [In: "Wild mammals of North America", J. A. Chapman, G. A. Feldhmamer, eds.]. Johns Hopkins University Press: 1-1147. Baltimore.

12. Chatterjee S. \& Price B., 1977: Regression analysis by example. John Wiley, New York.

13. Conover W. J., 1971: Practical nonparametric statistics, John Wiley: 1-462. New York.

14. Dixon W. J. \& Brown M. B., 1979: BMDP-79 biomedical computer programs P-series. Univ. Calif. Press: $1-880$. Berkeley.

15. Edwards W. R., Havera S. P., Labisky R. F., Ellis J. A. \& Werner R. E., 1981: The abundance of cottontails in relation to agricultural land use in Illinois (U.S.A.) 1956-1978, with comments on mechanism of regulation. [In: "Proceedings of the world lagomorph conference", K. Myers, C. D. MacInnes, eds.]. Univ. of Guelph: 1-983. Guelph, Ontario.

16. Fitzsimmons M., 1978: Influence of habitat on a west-central Indiana cottontail population. M.S. unpubl. thesis, Purdue Univ.

17. Friley C. E. Jr., 1955: A study of cottontail habitat preferences on a southern Michigan farming area. Mich. Dept. Conserv. Pittman-Robertson Proj. No. W-48-R.

18. Gordon M. S., Bartholomew G. A., Grinnell A. D., Jorgenson C. B. \& White F. N., 
1968: Animal function: principles and adaptations. MacMillan: 1-560. New York.

19. Gottfried B. M., 1979: Small mammal populations in woodlot islands. Amer. Midland Natur., 102: 105-112.

20. Grizzell R. A. Jr., A study of the southern woodchuck, Marmota monax monax. Amer. Midland Natur., 53: 257-293.

21. Hanson J. C., Bailey J. A. \& Siglin R. J., 1969: Activity and use of habitat by radio-tagged cottontails during winter. Trans. Illinois State Acad. Sci., 62: $294-302$.

22. Haugen A. O., 1943: Management studies of the cottontail rabbit in southwestern Michigan. J. Wildl. Manage., 7: 102-119.

23. Johnson A. M. \& Hendrickson G. O., 1958: Effects of weather conditions on the winter activity of Mearns Cottontail. Proc. Iowa Acad. Sci., 65: 554-558.

24. Kline P. D. \& Hendrickson G. O., 1954: Autumnal decimation of Mearns cottontail, Decatur County, Iowa, 1952. Proc. Iowa Acad. Sci., 61: 525-527.

25. Linder R. L. \& Hendrickson G. O., 1956: Use of rearing cover by Mearns cottontail. Proc. Iowa Acad. Sci., 63: 732-736.

26. Linduska J. P., 1947: Winter den studies of the cottontail in southern Michigan. J. Mammal., 28: 448-454.

27. Lord R. D. Jr., 1963: The cottontail rabbit in Illinois. Illinois Dept. Conserv. Tech. Bull. No. 3 .

28. Marsden H. M. \& Holler N. R., 1964: Social behavior in confined populations of the cottontail and the swamp rabbit. Wildl. Monogr., 13.

29. Petras M. L. \& Topping J. C., 1981: Studies of natural populations of Mus. VI. Sizes of population inhabiting corn cribs in southwestern Ontario. J. Mammal., 62: $146-153$.

30. Rao C. R., 1973. Linear statistical inference and its application. John Wiley: 1-625. New York.

31. Ricklefs R. E., 1976: The economy of nature. Chiron Press: 1-455. Portland.

32. Scott R. C., 1976: Extension educational programs on windbreaks and shelterbelts in the Great Plains states. [In: "Shelterbelts on the Great Plains", R. W. Tinus, ed.]. Great Plains Agric. Coun. Publ. No. 78: 201-203.

33. Smith A. T., 1980: Temporal changes in insular populations of the pika (Ochotona princeps). Ecology, 61: 8-13.

34. Smith M. \& Scholten H., 1980: Planting trees for farmstead shelter. Univ. Minnesota Agric. Ext. Serv. Bull. 196.

35. Swihart R. K. \& Yahner R. H., 1982: Eastern cottontail use of fragmented farmland habitat. Acta theriol., 27: 257-275.

36. Trent T. T. \& Rongstad O. J., 1974: Home range and survival of cottontail rabbits in southwestern Wisconsin. J. Wildl. Manage., 38: 459-472.

37. Trippensee R. E., 1938: Food relationships of the cottontail rabbit in southern Michigan. Trans. N. Amer. Wildl. Conf., 3: 794-804.

38. Vance R. D., 1976: Changes in land use and wildlife populations in southeastern Illinois. Wildl. Soc. Bull., 4: 11-15.

39. Vohries C. T. \& Taylor W. P., 1933: The life histories and ecology of jack rabbits, Lepus alleni and Lepus californicus ssp., in relation to grazing in Arizona. Arizona Agric. Exp. Stn. Tech. Bull. No. 49.

40. Wegner J. F. \& Merriam G., 1979: Movements by birds and small mammals between a wood adjoining farmland habitats. J. Appl. Ecol., 16: 349-357.

Accepted, October 15, 1983. 
Robert K. SWIHART i Richard H. YAHNER

\section{ZIMOWE WYKORZYSTANIE NIEJEDNORODNEGO SRODOWISKA PRZEZ SYLVILAGUS FLORIDANUS}

\section{Streszczenie}

W ciągu dwóch kolejnych zim, zajmowano się wykorzystaniem środowiska przez Sylvilagus floridanus (Allen, 1894) w południowo-wschodniej Minnesota. Badano charakterystykę strukturalną miejsc spoczynkowych i pokarmowych, drogą analizy dyskryminacyjnej (Tabela 1, 2, 3, 4). Stwierdzono, że S. floridanus ujawnia nieprzypadkowe wykorzystanie środowiska. Zależne jest ono od bliskości krzewów i okrywy abiotycznej nadającej się na miejsca dziennego odpoczynku i tereny żerowisk nocnych. Strefa posiadająca schronienia była używana częściej niż otwarte tereny a ogrodzenia przy drogach nie były wykorzystywane wogóle. Obecność krzewów, drzew iglastych i sztucznej okrywy w miejscach schronień i na otwartych terenach powodowała wzrost wykorzystywania tego typu środowiska przez S. floridanus. 